\title{
Benchmarking healthcare logistics processes: a comparative case study of Danish and US hospitals
}

\author{
Feibert, Diana Cordes; Andersen, Bjørn; Jacobsen, Peter
}

Published in:

Total Quality Management and Business Excellence

Link to article, DOI:

$10.1080 / 14783363.2017 .1299570$

Publication date:

2019

Document Version

Peer reviewed version

Link back to DTU Orbit

Citation (APA):

Feibert, D. C., Andersen, B., \& Jacobsen, P. (2019). Benchmarking healthcare logistics processes: a

comparative case study of Danish and US hospitals. Total Quality Management and Business Excellence, 30(12), 108-134. https://doi.org/10.1080/14783363.2017.1299570

\section{General rights}

Copyright and moral rights for the publications made accessible in the public portal are retained by the authors and/or other copyright owners and it is a condition of accessing publications that users recognise and abide by the legal requirements associated with these rights.

- Users may download and print one copy of any publication from the public portal for the purpose of private study or research.

- You may not further distribute the material or use it for any profit-making activity or commercial gain

- You may freely distribute the URL identifying the publication in the public portal 


\title{
Benchmarking Healthcare Logistics Processes - A Comparative Case Study of Danish and US Hospitals
}

\begin{abstract}
Logistics processes in hospitals are vital in the provision of patient care. Improving healthcare logistics processes provides an opportunity for reduced healthcare costs and better support of clinical processes. Hospitals are faced with increasing healthcare costs around the world and improvement initiatives prevalent in manufacturing industries such as lean, BPR and benchmarking have seen an increase in use in healthcare. This study investigates how logistics processes in a hospital can be benchmarked to improve process performance. A comparative case study of the bed logistics process and the pharmaceutical distribution process was conducted at a Danish and a US hospital. The case study results identified decision criteria for designing efficient and effective healthcare logistics processes. The most important decision criteria related to quality, security of supply and employee engagement. Based on these decision criteria, performance indicators were developed to enable benchmarking of logistics processes in healthcare. The study contributes to the limited literature on healthcare logistics benchmarking. Furthermore, managers in healthcare logistics are provided with a list of decision parameters relevant for designing and benchmarking processes.
\end{abstract}

Keywords: hospital logistics; benchmarking; performance measurement; bed logistics; pharmaceutical distribution; business process management 


\section{Introduction}

Healthcare systems across the world face the challenge of increasing costs due to an ageing population and more sophisticated treatments (OECD, 2015; Saltman \& Figueras, 1997; WHO, 2010). At the same time, patients are demanding high quality care at lower expenses. As a result, process improvement initiatives prevalent in manufacturing industries have seen an increase of use in healthcare, such as lean (Joosten, Bongers, \& Janssen, 2009; Souza, 2009), JIT (Heinbuch, 1995; Whitson, 1997), Six Sigma (Lifvergren, Gremyr, Hellström, Chakhunashvili, \& Bergman, 2010; Taner, Sezen, \& Antony, 2007), TQM (Chen, Chen, Wu, \& Lin, 2004; Kanji \& Moura e Sá, 2003), benchmarking (van Lent, de Beer, \& van Harten, 2010; van Lent, Sanders, \& van Harten, 2012), BPR (Bertolini, Bevilacqua, Ciarapica, \& Giacchetta, 2011; Ham, Kipping, \& McLeod, 2003), and automation (Falan \& Han, 2011; Poulymenopoulou, Malamateniou, \& Vassilacopoulos, 2012). Studies have shown that benchmarking is among the most implemented managerial approaches in hospitals along with TQM, care pathways, BPR and lean management (van Lent et al., 2012; Yasin, Zimmerer, Miller, \& Zimmerer, 2002). However, expected goals are far from always achieved upon implementation and hospitals are left to their experience and judgment in selecting an improvement approach (van Lent et al., 2012; Volland, Fügener, Schoenfelder, \& Brunner, 2016). Thus, there is a need for more rigorous studies on process re-design in healthcare (Elkhuizen, Limburg, Bakker, \& Klazinga, 2006), particularly on how to select suitable operations management best practices for implementation (Sousa \& Voss, 2008; Volland et al., 2016).

Logistical support processes in hospitals amount to over 30\% of hospital expenditure, half of which could be eliminated through benchmarking and best practice implementation (Aptel, Pomberg, \& Pourjalali, 2009; Mckone-Sweet, Hamilton, \& 
Willis, 2005; Poulin, 2003). Thus, logistical activities in hospitals provide significant opportunities for cost reductions in healthcare. Logistical activities include activities such as inbound and outbound transportation management, fleet management, warehousing, materials handling, order fulfillment, logistics network design, inventory management, supply/demand planning, and management of third party logistics services providers (Council of Supply Chain Management Professionals, 2015).

A hospital survey on the success of different managerial approaches, e.g. benchmarking, TQM and BPR, revealed that half of the hospitals had not achieved their goals upon implementation. Furthermore, no approach seemed to outperform the others (van Lent et al., 2012). The approach that best fits an organization is highly dependent on the context (Sousa \& Voss, 2001, 2008). Thus, Pan and Pokharel describe a set of parameters that characterize logistics activities in Singapore hospitals in order to identify improvement potential (Pan \& Pokharel, 2007), and Aronsson et al. identify what is important to consider when developing a supply chain in healthcare (Aronsson, Abrahamsson, \& Spens, 2011). Similarly, this paper identifies decision criteria to be considered when designing logistics processes within healthcare. The first research question addressed in this paper is therefore:

RQ1: Which decision criteria are consistent between Danish and US hospitals for designing efficient and effective healthcare logistics processes?

Efficiency is input oriented and is concerned with the economic use of resources, whereas effectiveness is output oriented and is concerned with achieving goals (Mentzer \& Konrad, 1991; Neely, Gregory, \& Platts, 2005). To enable process comparison, a benchmarking approach is applied. Benchmarking consists of a practice and a metric component (Camp, 1989b; C. A. Voss, Åhlström, \& Blackmon, 1997), but a benchmarking study does not necessarily include both (Hanman, 1997; Mayle, 
Hinton, Francis, \& Holloway, 2002). Benchmarking studies can be divided into a three step approach: 1) Determining current performance level, 2) Comparing performance with best practice, and 3) Planning how to reach or exceed best practice (Hanman, 1997). The second research question enables the first two steps:

RQ2: How can performance measures be defined based on the identified decision criteria in order to benchmark healthcare logistics processes?

This paper aims to develop a method for benchmarking logistics processes in hospitals that allows managers to select the process design that best fits their organization. A comparative case study of a Danish and US hospital was conducted investigating the bed logistics process and pharmaceutical distribution process. The paper applies a mixed methods approach and combines the use of qualitative and quantitative data to increase the validity of the study. Thus interviews, observations and documents are combined with quantitative assessments of the decision criteria by the involved decision makers. The study draws on literature from business process management, performance measurement and benchmarking.

\section{Literature review}

\section{Bed logistics and pharmaceutical distribution in hospitals}

The two process types investigated in this paper are the bed logistics process and the pharmaceutical distribution process. Pharmaceutical logistics is considered one of the most important logistics processes in hospitals, whereas the bed logistics process tends to rank lower in the minds of decision makers (Kriegel, Jehle, Dieck, \& Mallory, 2013). However, the bed logistics process is closely related to the vital patient flow as the bed flow is triggered by and partly follows the flow of the patient. Problems identified in patient flow logistics include patient flow variability caused by poor allocation of 
resources, lack of coordination between pipelines and production, and balancing elective and unscheduled demand (Villa, Prenestini, \& Giusepi, 2014). Optimizing patient flow logistics improves quality of care and optimizes the use of limited resources (Kriegel, Jehle, Dieck, \& Tuttle-weidinger, 2015; Kriegel, Jehle, Moser, \& Tuttle-Weidinger, 2016). Better planning of patient admission and assignment could help address the issues in patient flow logistics. At a strategic level, the problem hospitals face is a bed sizing problem and at an operational level, it is a bed planning problem (Bachouch, Guinet, \& Hajri-Gabouj, 2012). At a strategic level, mathematical models and simulation can be applied to calculate bed requirements within a hospital, e.g. (Utley et al., 2003; Zhu, Hen, \& Teow, 2012). At a more operational level, a decision support system using operational research techniques for admission planning and bed assignment could improve bed utilization, reduce dismissal rates (Bachouch et al., 2012; Schmidt, Geisler, \& Spreckelsen, 2013), and reduce the number of crowding beds (Holm, Lurås, \& Dahl, 2013). However, such an approach might not capture the complexity that characterizes a healthcare system, which could better be captured through simulation models (Holm et al., 2013) or a mixture of the two approaches, e.g. (Schmidt et al., 2013).

Some studies apply a more process oriented approach as the one taken in this paper. Thus, Villa and colleagues suggest a patient centric redesign of patient flow logistics to improve productivity and quality (Villa, Barbieri, \& Lega, 2009). Along the same lines, Kriegel and colleagues identify central patient admission, case management and patient discharge management as most important levers for improving patient flow (Kriegel et al., 2015, 2016). Chiarini demonstrates how mapping tools derived from lean, i.e. spaghetti charts, value stream mapping and activity worksheets can reduce distances traveled and time spent on patient transportation in hospitals (Chiarini, 2013). 
Furthermore, several authors have investigated the current use and potential for RFID in healthcare, e.g. to track and trace assets such as beds and linen (Kumar \& Rahman, 2014; Wamba \& Ngai, 2015; Wamba, Anand, \& Carter, 2013). Jehle and colleagues apply a benchmarking approach to patient transport logistics to identify areas for improvement (Jehle et al., 2015). Finally, Hastreiter and colleagues conduct a benchmarking study of patient transport in hospitals to identify areas for improvement (Hastreiter, Buck, Jehle, \& Wrobel, 2013). Thus, different process improvement tools have been applied and tested for the bed logistics process, including benchmarking.

The second process investigated in this paper is the pharmaceutical distribution process. The current trend of healthcare supply chains is a move toward global supply chains (Privett \& Gonsalvez, 2014). However, this results in complex coordination issues of the many agents in the supply chain with often differing objectives (Gebicki, Mooney, Chen, \& Mazur, 2014; Shah, 2004).

Several authors have analyzed the pharmaceutical supply chain from an operations research perspective by applying mathematical modelling, e.g. to optimize timing and batch sizes (Dobson, Tilson, \& Tilson, 2015), to reduce product and process waste (Tilson, Dobson, Haas, \& Tilson, 2014), and to cope with the complexity in the supply chain due to unpredictable demand and the multiple constraints that have to be taken into account for pharmaceutical products(Jurado et al., 2016).

Given the risk of adverse health effects from pharmaceutical products, the pharmaceutical industry is subject to stringent legislation. Thus, Elleuch and colleagues analyze a pharmaceutical supply chain from a risk perspective and propose a framework that applies a plethora of quantitative methods for risk assessment and risk mitigation purposes (Elleuch, Hachicha, \& Chabchoub, 2014). Furthermore, to reduce medical errors, healthcare providers have started implementing TQM to improve patient safety 
(Smith \& Offodile, 2008). Chen and colleagues provide an example of implementing TQM in a pharmaceutical logistics organization. The paper describes how TQM methods and tools can be successfully implemented in a healthcare pharmaceutical logistics organization and identifies four phases of TQM implementation: 1) awareness, 2) storming, 3) norming, and 4) performing. The TQM efforts resulted in cost reductions, sales increase and low employee turnover (Chen et al., 2004).

Different process reengineering tools have been tested for pharmaceutical supply chains. Pinna and colleagues investigate pharmaceutical logistics flow redesign and the advantages of a unit dose distribution system. In addition to more simplified processes, advantages include reductions in ward stock, pharmacy inventory, medicine cabinet management, and likelihood of errors (Pinna, Carrus, \& Marras, 2015). Al-Shaqha and Zairi provide case study examples of how re-engineering pharmaceutical processes can provide more patient-focused care by de-centralizing pharmacists to be part of the clinical care teams (Al-Shaqha \& Zairi, 2000). Papalexi and colleagues analyze the applicability of lean tools and suggest that implementing a kanban system in the pharmaceutical supply chain will significantly reduce inventory levels and inventory costs whilst improving quality of services through waste elimination and a more reliable product flow (Papalexi, Bamford, \& Dehe, 2016). Finally, Narayana and colleagues analyze the return of pharmaceuticals from a systemic point of view and identify factors impacting the reverse supply chain (Narayana, Elias, \& Pati, 2014).

Real-time information enables management and control of processes. Automated dispensing machines for pharmaceuticals products and sterile medical devices provide information on inventory levels at the point of use and can reduce stock-outs and stock levels, improve inventory accuracy and reduce time spent on inventory management (Bourcier et al., 2016; Gebicki et al., 2014; Rosales, Magazine, \& Rao, 2014). 
Furthermore, track and trace technologies such as RFID and barcodes have received increasing attention in healthcare supply chains (Wieser, 2011; Yazici, 2014). Thus, Chircu and colleagues study the application of RFID in an end-to-end pharmaceutical supply chain and identify benefits such as improved communication of data and information, reduced counterfeiting, and enabled monitoring of the quality of drugs (Chircu, Sultanow, \& Saraswat, 2014). Romero and Lefebvre investigate how track and trace solutions combining RFID and barcodes can improve a hospital’s internal pharmaceutical supply chain. However, according to the authors, little empirical evidence exists on how to improve internal logistics of pharmaceuticals (Romero \& Lefebvre, 2015), suggesting that more studies are needed on this topic.

\section{Benchmarking in hospitals}

There is a strong correlation between benchmarking and superior performance (C. A. Voss et al., 1997). Benchmarking has been defined as the search for industry best practices that lead to superior performance (Camp, 1989a). Since then, the definition of benchmarking has evolved into 'a management tool that can be defined as the systematic process of searching for best practices, innovative ideas and efficiencies that lead to continuous improvement' (Wong \& Wong, 2008). Thus, continuous improvement is an important aspect of benchmarking (Alstete, 2008; Dattakumar \& Jagadeesh, 2003; Hong, Hong, Roh, \& Park, 2012; Wong \& Wong, 2008). Gift and Mosel provide a definition of healthcare benchmarking as 'a continual and collaborative discipline, which involves measuring and comparing the results of key processes with the best performers and adapting best practices to achieve breakthrough process improvements in support of healthier communities’ (Mosel \& Gift, 1994). However, best practices can be costly to uncover and may never be identified. A more pragmatic definition of benchmarking is therefore 'a continuous, systematic process of measuring 
products, services and practices against organizations regarded to be superior with the aim of rectifying any performance "gaps”” (Kouzmin, Löffler, Klages, \& KoracKakabadse, 1999).

Lega and colleagues found that high performing hospitals are characterized by management that is oriented towards multidimensional performance, expresses clear goals, and utilizes management tools (Lega, Prenestini, \& Spurgeon, 2013). Research on performance indicators and benchmarking in healthcare mainly relates to patient care, e.g. care delivered in hospitals, primary care, patient experience, patient safety and mortality (Klazinga, Fischer, \& ten Asbroek, 2011), and the efficiency of physicians, but also hospital efficiency (Hussey et al., 2009). Almost half of healthcare efficiency measures in literature are ratios consisting of input and output metrics, the other half being econometric or mathematical programming methods (Hussey et al., 2009). One such mathematical programming method is Data Envelopment Analysis, which uses linear programming to identify an efficiency frontier based on observations of efficiency measures. This method has been used to benchmark hospital performance by comparing the efficiency of specific services, departments or entire hospitals (Chang, 1998; Lambert, Min, \& Srinivasan, 2009; Nayar, Ozcan, Yu, \& Nguyen, 2013; Ozcan, 2008). However, due to the small sample size of case organizations in this study, the DEA method was not applied, as the main strength of the method lies in the ability to compare across organizations of different sizes.

The provision of healthcare involves multiple actors and creates a complex environment for decision making (de Vries \& Huijsman, 2011). Hassan demonstrates how performance in healthcare can be measured based on the perception of multiple stakeholders to enable a comprehensive evaluation of business excellence. The engaged 
stakeholders include patients, staff, accreditation bodies and government authorities (Hassan, 2005).

Xiong and colleagues propose a measurement instrument that enables benchmarking of quality management practices and identification of best practices in hospitals. The instrument consists of nine constructs relating to 1) top management leadership, 2) quality policy, 3) role of the quality department, 4) training, 5) process management, 6) customer focus, 7) employee relations, 8) quality information and analysis, and 9) supplier quality management (Xiong, He, Ke, \& Zhang, 2015). These constructs could easily be applied to logistics practices in a hospital and some of the constructs can be characterized as logistics or supply chain measures.

In some healthcare systems, the need for benchmarking lies not only with the provider but also with the consumer, i.e. patient. In a study by van der Wees and colleagues, performance measurement in the healthcare systems of Massachusetts and the Netherlands are compared. The authors identify three main challenges related to comparing performance. First, to create quality measures that can be used at both the clinical quality improvement level and at the aggregate accountability level. Second, to establish a set of standardized quality measures and avoid information overload. Third, to present easily understandable and customized information to the consumers as decision support (Van der Wees et al., 2014).

Some benchmarking studies in healthcare take a different approach than the typical measures related to care and hospital efficiency. E.g. Sargiacomo uses internal benchmarking to compare staff motivation and satisfaction between wards and health districts of the same healthcare provider. A benchmark amongst the departments was identified based on staff ratings of a set of indicators reflecting staff motivation and 
satisfaction. Areas for improvement were subsequently identified and recommendations to fill the performance gap suggested (Sargiacomo, 2002).

\section{Identifying best practices and benchmarking healthcare logistics processes}

A structured literature review by Dobrzykowski and colleagues established that the design of healthcare delivery systems was one of the most prevalent topics in healthcare supply chain management (SCM) and operations management literature. However, measurement of services was one of the least researched topics (Dobrzykowski, Deilami, Hong, \& Kim, 2014). How to measure performance in hospital logistics is therefore a major research opportunity in the field of healthcare logistics (Volland et al., 2016). Hastreiter and colleagues identified 19 articles relevant to benchmarking logistics services in hospitals and found that the topic has gained importance in recent years. However, the limited number of relevant articles included in the review suggests that literature on this topic remains scarce (Hastreiter et al., 2013).

Benchmarking seeks to identify best practices and aims to match or exceed best in class performance. Best practices from fields such as SCM and business process management (BPM) can offer opportunities for improvement in healthcare, e.g. (Aitken, Childerhouse, Deakins, \& Towill, 2016; Callender \& Grasman, 2010; Hung, 2006). However, the healthcare sector has not reaped the same benefits from adopting SCM practices as other industries. Despite many healthcare organizations having recognized the importance of adopting SCM practices (de Vries \& Huijsman, 2011), continued lack of executive management support for SCM practices and failing to align incentives across the healthcare supply chain have led to poor supply chain performance in the healthcare industry (Mckone-Sweet et al., 2005).

Korpela and Tuominen define five critical success factors in logistics: reliability, flexibility, lead time, cost-effectiveness and value-added. They apply the Analytic 
Hierarchy Process (AHP) method to determine logistics performance and enable comparison of logistics performance across companies (Korpela \& Tuominen, 1996). At a more strategic level, Díaz and colleagues benchmark supply chain and logistics practices of Spanish companies to best practices identified in literature. The best practices identified and benchmarked include the following (Díaz, Claes, Solís, \& Lorenzo, 2011):

- Top management understanding and support of SCM

- $\quad$ Strategic focus on cost effectiveness

- Integration towards suppliers

- Strategic relations with suppliers

- High degree of trust

- Measuring logistics and supply chain performance indicators

Thus, differing views exist on what constitutes as best practices in supply chain management and logistics. However, several authors mention managers' understanding of and support of SCM and logistics initiatives as pivotal to the success of implementing these practices (Callender \& Grasman, 2010; Díaz et al., 2011; MckoneSweet et al., 2005; Ralston, Grawe, \& Daugherty, 2013). Lack of management commitment can lead to benchmarking being superseded by other management approaches such as BPR that may experience the necessary executive attention (Simpson, Kondouli, \& Wai, 1999).

Few studies exist on best practices in healthcare logistics. Callender and Grasman recommend a set of best practices for material management in healthcare based on SCM practices. These best practices relate to education, inventory management, procurement and contracting, and information sharing and 
collaboration/cooperation. The recommendations include increased training and education on SCM practices, the use of computer software to manage inventories, automating ordering processes using EDI or Internet based solutions, sharing inventory related information with vendors, and finally involving healthcare providers such as physicians in product selection. These best practices can help material managers provide services at a lower cost whilst maintaining quality of care. Callender and Grasman furthermore identified a list of barriers to SCM practices: conflicting goals regarding inventory, constantly evolving technologies, physician preferences for certain products, lack of barcode standards for products, and finally limited information sharing (Callender \& Grasman, 2010). In addition, investigating supply chain innovation as a SCM practice in healthcare, Lee and colleagues found that supply chain innovation positively affects supplier cooperation, supply chain efficiency and quality management practices, which in turn improves the organizational performance in hospitals (S. M. Lee, Lee, \& Schniederjans, 2011).

A benchmarking study of the organization of operating theaters by Longo and Masella considers both clinical and logistical processes. Logistics and support processes such as patient transport, cleaning of the operating theater, management of medical aids, management of medical instruments, and sterilization of components are included in the investigation. The AHP method is used to evaluate scenarios for different types of processes to identify best practices. The study identifies quality, income and costs as performance drivers and conducts an AHP analysis that considers three underlying criteria to identify best practices: perceived quality, environmental quality, and value added (Longo \& Masella, 2002). Along the same lines, Hastreiter and colleagues propose a benchmarking approach for healthcare logistics services that measures productivity, quality and costs. This approach is applied to six German hospitals to 
enable comparison of logistics service performance (Hastreiter et al., 2013). Similarly, Jehle and colleagues perform a benchmarking study of patient transport logistics in six German hospitals measuring productivity, quality and costs. They identify six factors affecting performance: 1) variability in transport demand, 2) number of transports, 3) number of acute and operating theater transports, 4) number of lifts for people and beds, 5) number of floors, and 6) number of bed and patient transports (Jehle et al., 2015).

Benchmarking the supply of materials is another aspect of healthcare SCM that holds great potential for cost savings. First, by helping ensure that hospitals do not pay overprices for products and second, by helping improve contracts with suppliers (Troolin, 2000). Böhme and colleagues provide a practice focused benchmarking study on the reliability of medical healthcare supplies in hospitals. They identify failure of management to recognize the importance of supplies together with poor management systems in the supply chain as reasons for poor supply chain performance (Böhme, Williams, Childerhouse, Deakins, \& Towill, 2016).

In addition to the forward flow of goods, a reverse flow exists for products such as pharmaceuticals. Xie and Breen benchmark the logistics systems of household waste pharmaceuticals against the reverse logistics of batteries and identify opportunities for improving reverse logistics of pharmaceutical products (Xie \& Breen, 2014). Thus, the benchmarking study compares a reverse logistics process in healthcare to a reverse logistics process of another industry but with similar characteristics.

Other studies include Swinehart and Smith, who provide a method for using internal customer satisfaction data to measure internal healthcare supply chain performance (Swinehart \& Smith, 2005). Lega et al. provide a framework for measuring supply chain performance in the public healthcare sector based on three dimensions: 1) set-up and operating costs, 2) financial benefits, and 3) organizational and process 
benefits (Lega, Marsilio, \& Villa, 2012). Finally, Villa and colleagues propose a framework for evaluating patient flow performance at three different levels: 1) hospital, 2) hospital pipelines, and 3) production units (Villa et al., 2014).

Some challenges relating to benchmarking healthcare logistics have been identified in literature. First, examples from the UK show that benchmarking within healthcare has served more as a political instrument than a vehicle for sharing best practice. Moreover, benchmarking led to hospitals taking a defensive stance trying to justify differences in performance rather than promoting continuous improvement (Northcott \& Llewellyn, 2005). Second, identifying best practice and developing comparable benchmarks is particularly challenging in public and healthcare settings (Kouzmin et al., 1999; Magd \& Curry, 2003; Northcott \& Llewellyn, 2003; WynnWilliams, 2005). Third, benchmarking supply chains in particular poses some methodological challenges due to lack of information and political agendas (Böhme, Williams, Childerhouse, Deakins, \& Towill, 2013). Another issue with benchmarking supply chains is that most methodologies do not take into account that the importance of different performance measures and best practice aspects varies across firms (Simatupang \& Sridharan, 2004). Finally, international benchmarking of hospitals is particularly challenging due to the added complexity of comparing different healthcare systems (van Lent et al., 2010).

This literature review shows that there is no consistent way of measuring supply chain and logistics performance in healthcare and thus agrees with the findings of Mckone-Sweet and colleagues (Mckone-Sweet et al., 2005). Literature on benchmarking healthcare logistics processes is limited and challenges related to benchmarking healthcare logistics and supply chain processes have been identified. The 
current paper helps fill the literature gap and cope with the challenges identified for healthcare logistics and supply chain benchmarking.

\section{Method}

A case study was chosen as research design because it provides in-depth knowledge of a phenomenon (Yin, 1994). The case studies investigated in this paper are within the field of operations management, which is suitable for case studies and empirical studies (McCutcheon \& Meredith, 1993; C. Voss, Tsikriktsis, \& Frohlich, 2002). Moreover, a comparative case study was chosen to improve the validity of findings.

The comparative case study consists of a multiple case study at five Danish hospitals and two case studies at a US hospital. The Danish hospitals were chosen because they are located within the same region and underlie the same governance structure and budget constraints. The US hospital was chosen because it ranks as a good hospital in the US and provides a suitable basis for comparison. The case study hospitals are considered representative for hospitals in their respective countries and for hospitals in general.

The Danish multiple case study considered the bed logistics process at five Danish hospitals. The study conducted in Denmark was subsequently replicated for the bed logistics process and pharmaceutical distribution process at a US hospital. The bed logistics process in the US was chosen to generalize the findings from Denmark to a US setting. The pharmaceutical distribution process in the US was chosen to generalize the findings from the bed logistics process to other logistical processes.

Data was collected for the Danish study from February to August 2014 and for the US case studies from September 2015 to January 2016. Collected data was qualitative and quantitative in nature and was mainly gathered through interviews, observations, and a survey. Interview and observation guides were used to guide data 
collection in a three stage process. First, direct process observations of each process step were carried out to map the processes. Second, a round of semi-structured interviews was carried out to learn more about the process steps, challenges, and implemented changes in order to identify decision criteria (see Appendix A). Third, a survey or structured interview was conducted to validate the identified decision criteria (see Appendix B). At this stage, the respondents weighted each of the identified decision criteria according to importance for the design of their processes. For the Danish bed logistics case study, 12 observations, 16 semi-structured interviews, and five structured interviews were carried out. For the US bed logistics case study, data was collected through four observations, seven semi-structured interviews, and a survey sent to three respondents. For the US pharmaceutical distribution case, data was collected through three observations, six semi-structured interviews, and a survey sent to two respondents. The interviews lasted between $1 / 2-1 \frac{1}{2}$ hour and the observations lasted between $1 / 2-1$ hour.

Interview participants were selected based on their knowledge of the processes or their roles as decision makers. In the Danish bed logistics study, 12 people were interviewed in one of the hospitals, including managers from the transport department, cleaning department, and maintenance department. Furthermore, staff involved in data management in addition to clinical staff, represented by a physician and a nurse, were interviewed. The number of interview participants was determined by the number of process steps, key decision makers and knowledge workers at each process step. This was to gain initial in-depth knowledge of the bed logistics process before gathering data at other hospitals. In the four other Danish hospitals, the manager of the bed logistics process was interviewed in both the semi-structure and structured interviews/surveys. In the US, an interview person was selected from each step of the process to gain more in- 
depth knowledge of each process step. For the US bed logistics process, seven people were interviewed, including managers from Bed Management, Environmental Services, and Patient Transport Services. Three managers subsequently participated in a structured interview or survey, i.e. one from each department. For the US pharmaceutical distribution process, five managers from the Inpatient Pharmacy, IT department, and the Continuous Improvement department were interviewed. A manager from the Inpatient Pharmacy and a manager from the Continuous Improvement department subsequently responded to a survey/participated in a structured interview.

The decision criteria (RQ1) developed in this study are based on the data gathered and analyzed in the case studies, thus adopting an inductive approach for linking data to results. Decision criteria were identified by coding interview and observation data according to three analyses: 1) identifying challenges in the process, 2) identifying reasons behind implementing technologies, and 3) identifying reasons behind implementing process changes. Challenges reflect the improvement potential in a process to reach organizational goals (Locke \& Latham, 2002; VandeWalle, Cron, \& Slocum Jr., 2001), and reasons behind implementing technologies and process changes reflect decision criteria used in the past to improve processes. The identified challenges and reasons for implementing technologies and process changes were coded in the collected data. Patterns emerged within the codes and themes could thus be identified. Coding was an iterative process with patterns emerging that formed the decision criteria. The decision criteria that emerged from the codes were validated in the structured interviews/surveys where the identified decision criteria were ranked by key decision makers on a 0-10 scale of importance for designing logistics processes. The decision criteria were continuously adjusted during this validation process. The decision criteria identified and validated in the Danish case study were subsequently validated 
for the US case studies by conducting the same three analyses of data and validating findings in structured interviews/surveys.

To determine best practice benchmarks (RQ2), a range of the best KPIs in the relevant area were determined (Hanman, 1997), i.e. performance measures that reflect the objectives of the organization (Camp, 1995). The decision criteria ranked as most important for the Danish and US case studies were thus identified as those reflecting the objectives of the organization and as relevant areas for measuring KPIs. Performance metrics were therefore suggested within these areas to determine best practice benchmarks.

\section{Case study descriptions and initial comparison}

The five Danish case study hospitals are public hospitals located in the capital region of Denmark. These hospitals vary in size from 250 to 700 beds. The US hospital is one of the top ranking hospitals in the country. It is a nonprofit organization with several locations across the US and outside of the US. The main campus with approximately 1,250 beds is the main focus of this study. An overview of the case study hospitals can be found in Table 1.

Table 1. Overview of case study hospitals and their emergency department (ED) services

\begin{tabular}{lccc}
\hline Hospital & \# beds & $\begin{array}{c}\text { \# discharge beds } \\
\text { cleaned/day }\end{array}$ & 24hr ED in hospital? \\
\hline DK hospital 1 & 700 & 235 & Yes \\
DK hospital 2 & 600 & 250 & Yes \\
DK hospital 3 & 500 & 175 & Yes \\
DK hospital 4 & 400 & 110 & No \\
DK hospital 5 & 250 & 120 & No \\
US hospital & 1,250 & 200 & Yes \\
\hline
\end{tabular}


The Danish and US hospitals operate under very different circumstances. In contrast to the government funded healthcare provided in Denmark, US healthcare is funded by insurance companies, government programs, self-pay, donations, and grants. The financial structure also differs in the sense that US hospitals are partly reimbursed by government programs based on hospital performance and patient satisfaction (Geiger, 2012; G. M. Lee et al., 2012; Rosenthal, 2007).

The bed logistics flow in the Danish hospitals involves the patient being placed in bed and undergoing treatment. When the patient is discharged, the bed is transported to a central cleaning area where the bed is cleaned and transported to a new patient. The beds are either cleaned manually or in washing machines. The clinical departments are responsible for bed assignment and patient discharges; the cleaning department cleans the rooms; the transportation department transports patients to treatment, clean beds to patients, and dirty beds to the central bed cleaning team. Throughout the process, limited process data is available apart from admission and discharge data.

The US bed logistics process is similar to the Danish bed logistics process, the only difference being that beds are cleaned in the wards. Furthermore, the information level in the US bed logistics process is higher than for the Danish process. In addition to admission and discharge data, certain time stamps are registered for patient transport and cleaning through a teletracking system. A range of organizational units are involved in the bed logistics process; Bed Management assigns beds, Cleaning Services cleans rooms and beds, Transportation transports patients to the assigned rooms and to/from treatments, and the clinical departments admit and discharge patients.

The US pharmaceutical distribution process investigated in this paper focuses on the inpatient pharmacy. Pharmaceuticals are transported from the docking area to the inpatient pharmacy where they are checked with the orders. They are then transferred to 
the storage area where they are registered and stored in a picking carousel. Throughout the day, pharmaceuticals are picked from the carousel and delivered to clinical departments, where they are registered and stored in dispensing stations before being administered to the patients. The dispensing stations are refilled daily from the central inventory at a pre-scheduled time, whereas patient specific pharmaceuticals are sent to the departments separately throughout the day. Pharmaceuticals are either transported manually or through pneumatic tubes. Between each handover in the process, pharmaceuticals are scanned using barcodes in order to enable item tracking and to ensure that the correct items are handed over. At any point in time, the location of any pharmaceutical is known from the point of delivery in the pharmacy until it is administered to the patient. Most of the process is handled within one organization, namely the Inpatient Pharmacy.

Comparing the bed logistics process to the pharmaceutical distribution process, the bed logistics process is characterized by disjunctive process steps that involve staff from several different departments who possess very different skill sets. Furthermore, most of the process steps are performed manually. By contrast, the pharmaceutical distribution process is handled by fewer departments and is a more automated process. Process automation provides data to enable performance measurement, analytics and process improvement. Another significant difference between the bed logistics and pharmaceutical distribution processes is found in the characteristics of the items and flows. The pharmaceutical distribution process concerns the flow of small sized items that enter the system from an external source, i.e. the pharmaceutical manufacturers and wholesalers, and exits either at the point of consumption, when returned to the vendors, or when being disposed of. The bed flow, on the other hand, is a closed-loop flow of large items, i.e. beds, which enter the system once, are reused and finally exit the 
system when replacement is needed. The bed flow follows the patient flow to some extent and is used as a vehicle for transport, whereas pharmaceuticals are part of the patient treatment and encounter the patient at the point of consumption. Finally, the pharmaceutical distribution process is characterized by a higher degree of control due to strict legislation.

\section{Results}

\section{Identifying and validating decision criteria}

Decision criteria were identified by coding interview and observational data according to 1) challenges identified in the processes, 2) reasons behind implementing technologies, and 3) reasons behind implementing process changes. Examples of the links between data and decision criteria are provided for each of the three analyses in the following.

1) Challenges. A main challenge in the pharmaceutical distribution process was how to use available information to make critical decisions faster and to optimize the use of technologies. E.g. data was used to ensure the right inventory mix so that enough on-demand drugs were available while at the same time limiting storage space. These challenges relate to the derived decision criterion information management.

2) Technologies. AGVs were implemented to transport pharmaceuticals from the docking area to the pharmacy. The AGVs were also used for transporting linen as well as other items around the hospital. The AGVs were implemented because of their fast response and delivery time in addition to prevention of employee injuries relating to manual transports. Derived decision criteria based on these arguments are lead time, degree of automation, employee work conditions, and impact on related processes. 
3) Process changes. A rigid seven step cleaning process had been implemented in the US bed logistics process. This seven step process was implemented to limit variance in the process and ensure a consistent result that lives up to cleaning requirements. Decision criteria derived from this analysis are consistency, risk of mistakes, output quality, and competence match.

To further exemplify the logic used to link data and derived decision criteria, a full overview of the link between data and decision criteria is provided for the analysis of technologies in the US pharmaceutical distribution process in Table 2. To economize on space, a full overview of the link between data and decision criteria is provided only for this analysis. However, the logic extends to all three cases and analyses. The example was chosen because it provides the most extensive illustration.

The described approach for identifying decision criteria was performed for all three case studies. Seventeen decision criteria were identified in the Danish and US case studies. Each of these decision criteria were weighted by Danish and US respondents according to importance regarding process design. Table 3 shows the average weights assigned by the Danish and US hospitals for the seventeen decision criteria. The table is sorted in descending order according to the average weights for all respondents. The standard deviation (SD) for all respondents is lowest for the highest ranking decision criteria and seems to increase as the average importance of decision criteria decreases. This trend suggests that there is consensus across respondents for the highest ranking decision criteria and less consensus for the lowest ranking criteria. Furthermore, there seems to be more agreement amongst respondents from the same country than respondents from the same process type. 
Table 2. Decision criteria derived from identified technologies in the US pharmaceutical distribution process

\begin{tabular}{|c|c|c|}
\hline Technology & Reasons for implementation and benefits & Derived decision criteria \\
\hline$\overline{\text { AGVs }}$ & $\begin{array}{l}\text { Transport pharmaceuticals to the pharmacy. } \\
\text { Response time is fast and solution financially } \\
\text { viable (also used for other transports). Saves } \\
\text { injuries as carts are heavy. }\end{array}$ & $\begin{array}{l}\text { Lead time } \\
\text { Degree of automation } \\
\text { Employee work conditions }\end{array}$ \\
\hline EPIC & $\begin{array}{l}\text { EPIC stores electronic medical and } \\
\text { pharmaceutical records. The CPOEs } \\
\text { (computerized physician order entry) and } \\
\text { prescriptions are entered into Epic. }\end{array}$ & $\begin{array}{l}\text { Degree of automation } \\
\text { Value-added time } \\
\text { Information management }\end{array}$ \\
\hline Pneumatic tubes & $\begin{array}{l}\text { Pneumatic tubes are used for small } \\
\text { pharmaceutical transports in cases of emergency. } \\
\text { Transport time is } 10-20 \text { minutes. }\end{array}$ & $\begin{array}{l}\text { Degree of automation } \\
\text { Lead time }\end{array}$ \\
\hline $\begin{array}{l}\text { Picking } \\
\text { carousels }\end{array}$ & $\begin{array}{l}\text { Automated carousels are used for picking } \\
\text { pharmaceuticals. The carouse indicates which } \\
\text { drawer in to pick from, and a technician then } \\
\text { picks the drugs. }\end{array}$ & $\begin{array}{l}\text { Degree of automation } \\
\text { Future proofing }\end{array}$ \\
\hline $\begin{array}{l}\text { Medication } \\
\text { dispensing } \\
\text { stations }\end{array}$ & $\begin{array}{l}\text { Ensures availability of pharmaceuticals close to } \\
\text { the patient and involves safety mechanisms for } \\
\text { the patient. }\end{array}$ & Security of supply \\
\hline MRP system & $\begin{array}{l}\text { An MRP system is used that enables inventory } \\
\text { management, purchasing, and finance. }\end{array}$ & $\begin{array}{l}\text { Degree of automation } \\
\text { Information management }\end{array}$ \\
\hline EDI & Enables automatic reordering of pharmaceuticals. & $\begin{array}{l}\text { Degree of automation } \\
\text { Value-added time } \\
\text { Information management }\end{array}$ \\
\hline Med boards & $\begin{array}{l}\text { Visual boards that together with barcodes enable } \\
\text { tracking of pharmaceuticals - it is possible to see } \\
\text { where the meds are at any particular moment in } \\
\text { time. }\end{array}$ & $\begin{array}{l}\text { Traceability } \\
\text { Information management }\end{array}$ \\
\hline Barcodes & $\begin{array}{l}\text { Barcodes are used for tracking pharmaceuticals } \\
\text { and for bedside verification. The patient's } \\
\text { wristband and the pharmaceutical are scanned for } \\
\text { verification. }\end{array}$ & $\begin{array}{l}\text { Traceability } \\
\text { Information management }\end{array}$ \\
\hline RFID & $\begin{array}{l}\text { Code boxes are tracked and through RFID } \\
\text { technology. }\end{array}$ & Traceability \\
\hline
\end{tabular}


Table 3. Decision criteria weighted by the five Danish hospitals and the US hospital

\begin{tabular}{|c|c|c|c|c|c|}
\hline \multirow{3}{*}{$\begin{array}{l}\text { Existing decision } \\
\text { criteria }\end{array}$} & \multirow{3}{*}{$\begin{array}{c}\begin{array}{c}\text { Weights for DK } \\
\text { bed logistics } \\
\text { case }\end{array} \\
5 \\
\text { Average }\end{array}$} & \multirow{2}{*}{$\begin{array}{c}\begin{array}{c}\text { Weights for US } \\
\text { bed logistics } \\
\text { case }\end{array} \\
3 \\
\end{array}$} & \multirow{2}{*}{$\begin{array}{c}\text { Weights for US } \\
\text { pharmaceutical } \\
\text { distribution case }\end{array}$} & \multicolumn{2}{|c|}{$\begin{array}{l}\text { Weights for all } \\
\text { respondents }\end{array}$} \\
\hline & & & & \multicolumn{2}{|c|}{10} \\
\hline & & Average & Average & Average & $S D$ \\
\hline Output quality & 9.8 & 9.0 & 9.5 & 9.4 & 1.0 \\
\hline Consistency & 9.4 & 9.3 & 9.5 & 9.4 & 1.0 \\
\hline $\begin{array}{l}\text { Employee } \\
\text { engagement }\end{array}$ & 9.4 & 9.7 & 9.0 & 9.4 & 1.1 \\
\hline Risk of mistakes & 10.0 & 8.0 & 10.0 & 9.4 & 1.6 \\
\hline Security of supply & 9.4 & 8.7 & 10.0 & 9.3 & 1.5 \\
\hline $\begin{array}{l}\text { Information } \\
\text { management }\end{array}$ & 8.4 & 9.3 & 10.0 & 9.0 & 1.5 \\
\hline $\begin{array}{l}\text { Employee work } \\
\text { conditions }\end{array}$ & 9.6 & 8.7 & 8.0 & 9.0 & 1.7 \\
\hline Lead time & 8.4 & 8.7 & 8.5 & 8.5 & 2.0 \\
\hline Traceability & 7.4 & 9.3 & 10.0 & 8.5 & 2.5 \\
\hline Value-added time & 8.5 & 8.3 & 8.0 & 8.4 & 2.0 \\
\hline $\begin{array}{l}\text { Impact on related } \\
\text { processes }\end{array}$ & 8.3 & 9.0 & 5.0 & 7.9 & 2.1 \\
\hline $\begin{array}{l}\text { Unnecessary } \\
\text { process }\end{array}$ & 6.3 & 8.3 & 8.0 & 7.3 & 2.3 \\
\hline Competence shift & 5.6 & 9.0 & 8.5 & 7.2 & 3.2 \\
\hline Future proofing & 8.0 & 6.3 & 5.5 & 7.0 & 2.7 \\
\hline $\begin{array}{l}\text { Competence } \\
\text { match }\end{array}$ & 5.6 & 8.3 & 8.0 & 6.9 & 3.3 \\
\hline $\begin{array}{l}\text { Degree of } \\
\text { automation }\end{array}$ & 7.8 & 5.7 & 5.5 & 6.7 & 2.7 \\
\hline $\begin{array}{l}\text { Environmental } \\
\text { considerations }\end{array}$ & 9.0 & 5.3 & 1.5 & 6.4 & 3.5 \\
\hline
\end{tabular}

Identifying the most important decision criteria to enable benchmarking

Measuring performance aspects that are considered important for all processes enables benchmarking. It would be biased to compare performance metrics that are of high importance in one case study and low for another as low performance could then be attributed to low importance. Table 3 shows the identified decision criteria in descending order according to importance for improving healthcare logistics processes. The five most important decision criteria based on Table 3 are as follows: 
- $\quad$ Output quality

- Consistency

- Employee engagement

- Risk of mistakes

- Security of supply

Each of these five decision criteria are now discussed in turn and compared for the three cases. Furthermore, suggestions for how these decision criteria could be operationalized as performance metrics to enable benchmarking are proposed.

Risk of mistakes could be measured based on the error rate occurring in a process. In the US pharmacy, the error rate for picking pharmaceuticals is currently measured. In the US bed logistics process, patient satisfaction is measured for all patients and cleanliness is checked daily by supervisors for a random sample of rooms. Similarly, a random sample of rooms is checked for the Danish bed logistics process. However, it is time consuming to check the cleanliness of a room and applying a tool such as six sigma could therefore prove difficult. Six sigma reflects the likelihood of an error occurring by measuring variability in terms of the standard deviation. However, the low defect rate for a $6 \sigma$ process of 3.4 defects per million may not be necessary for logistics processes in healthcare. A higher standard deviation may be allowed, e.g. three sigma, leading to less consistency in the process. The allowed level of variability may therefore vary depending on the process and how easy it is to measure variability. Lastly, output quality refers to how good a product or a service is. This is the notion of quality as “conformance to requirements” (Crosby, 1979; Lewis \& Hartley, 2001); output quality being the requirement and level of tolerated failure being the allowed variance. Some of the Danish hospitals use washing machines to wash the beds, which leads to cleaner beds than when they are washed by hand. Employees washing the beds 
by hand are not necessarily making a mistake, but the conditions are not there to achieve the same level of cleanliness. However, mistakes are more likely to occur in a manual process. A system may therefore only allow for certain levels of output quality. Another output quality measure could be the level of service provided. E.g. service level agreements on lead time were established for patient transports and discharge room cleaning in the US hospital.

Employee engagement. Motivation of employees and ensuring employee engagement was identified as a challenge in all case studies. However, 'how do you motivate someone that isn't really motivated?' as a manager in bed logistics pointed out. Employee turnover and absenteeism was high in all the case studies. It is therefore important to measure employee turnover and absenteeism, e.g. the average number of sick days per employee or the absence rate. Furthermore, to ensure employee retention, measuring employee satisfaction and finding out the reasons behind employee satisfaction levels is vital. This could be done through periodical surveys, talking to the employees or having the employees indicate job satisfaction levels daily through a red/green/yellow ‘traffic light' or 'smiley’ system, which are frequently used reporting structures (Neely, Adams, \& Kennerley, 2002). Another measure of employee engagement or employee involvement as suggested by Neely and colleagues is the percentage of employees providing a number of implementable improvement suggestions (Neely et al., 2002).

Security of supply is particularly important for pharmaceuticals due to the impact on patient treatment. A way to monitor security of supply would be to measure the rate of fulfilled orders by suppliers or the rate of fulfilled patient orders. The hospital may be able to accommodate hospital demand for a while without replenishing stock, but for how long would depend on the reorder point for each product. For the bed logistics 
process, supply refers to either 1) cleaning supplies, 2) supply of clean beds or 3) supply of transport and cleaning staff. First, shortages in cleaning supplies do not occur as the items do not have an expiration date and are easy to restock. Secondly, shortages in the supply of clean beds translate into waiting time for the patients, which could be measured as time-to-bed assignment for patients. Finally, shortages in cleaning staff have occurred for the US hospital, particularly when the area experienced a snow storm and many employees could not get to work. Despite the lack in resources, the hospital still managed to clean all rooms to a fair standard. Therefore, security of supply does not apply to the supply of human resources and cleaning supplies in the bed logistics process.

\section{Discussion}

There seems to be consensus across respondents on high ranking decision criteria and less consensuses as the average weight of importance decreases. The results suggest that disagreement on importance of the lower ranking decision criteria depends on the specific process type and national context. Hence, international benchmarks may differ slightly compared to benchmarks with peers restricted to a national level. Conversely, the agreement on the higher ranking decision criteria suggests that these decision criteria are of high important regardless of context and process type. Overall, the identified decision criteria, except for environmental considerations, were found valid in both a Danish and US context and for bed logistics processes as well as other hospital logistics processes such as pharmaceutical distribution. Furthermore, the decision criteria address both efficiency and effectiveness aspects of performance; e.g. downtime and maintenance and eliminating unnecessary processes address efficiency, whereas output quality and employee engagement address effectiveness. Thus, RQ1 is answered through the validation of decision criteria for the Danish and US case studies. 
Quality measures, employee engagement, and security of supply were identified as the most important aspects of healthcare logistics processes. In addressing RQ2, performance indicators were suggested based on these decision criteria. Existing benchmarking studies on healthcare logistics have focused on customer satisfaction (Swinehart \& Smith, 2005), organizational benefits, process benefits including quality service levels, financial benefits, and set-up and operating costs (Lega et al., 2012). The quality aspects considered by Lega et al. are delivery performance, time to deliver, flexibility, distribution of workloads, and accuracy and timeliness of information (Lega et al., 2012). Most of these aspects relate to lead time or time savings, which in this study corresponds to the suggested output quality measures on lead times for transport and discharge cleaning. The need for methods that incorporate quality in benchmarking in healthcare is therefore addressed (Hussey et al., 2009). Delivery performance as mentioned by Lega et al. relates to the identified decision criterion security of supply. A benchmarking study by Böhme and colleagues investigates how to improve the reliability of value streams in hospitals (Böhme et al., 2016), which can be similarly translated into the decision criterion security of supply. Thus, two of the most important aspects of healthcare logistics identified in this study are consistent with existing literature. Moreover, this paper recognizes the importance of reliability in healthcare value streams and contributes to the literature on how to improve reliability of value streams in hospitals.

The last benchmark and decision criterion identified in this study is employee engagement. Making sure that the right employees with the right skills are hired is one of the main challenges identified in the pharmaceutical supply chain and is vital for further supply chain improvements (Privett \& Gonsalvez, 2014). Human factors are often overlooked in operations management literature, but failure to recognize the 
importance of human factors in operations design can impede operational performance (Boudreau, Hopp, McClain, \& Thomas, 2003; Grosse, Glock, Jaber, \& Neumann, 2015). Typical human resource management (HRM) studies investigate the effect of certain HRM practices on individual behavior such as turnover, absenteeism, job satisfaction and performance, e.g. (Boudreau et al., 2003; Huselid, 1995; Rodwell, Lam, \& Fastenau, 2000). Similarly, employee satisfaction, turnover and absenteeism metrics were suggested as important metrics in this study to capture employee engagement. The challenge of high absenteeism and turnover in logistics settings has been reported in logistics literature, e.g. (Grosse et al., 2015; Min, 2004, 2007), and is validated in this study for a healthcare logistics setting. Some benchmarking literature in healthcare recognizes the importance of human factors and HRM (Sargiacomo, 2002; Xiong et al., 2015). However, literature on healthcare logistics fails to recognize the importance of the human factor and HRM. The current paper identifies human factors as important in the delivery of high quality logistics services in hospitals and recommends that human factors are considered in benchmarking efforts.

Quality seems to be a recurring aspect identified in this study and benchmarking literature within healthcare logistics (Hastreiter et al., 2013; S. M. Lee et al., 2011; Longo \& Masella, 2002), service logistics (Altuntaş Vural \& Tuna, 2016; Blumberg, 1994; Kilibarda, Zečević, \& Vidović, 2012; Thai, 2013), and manufacturing logistics (Bagchi, 1996; Daugherty, Dröge, \& Germain, 1994; Landeghem \& Persoons, 2001). The time aspect is also a recurring theme, which in turn relates to the quality aspect in healthcare logistics. Finally, Landeghem and Persoons mention flexibility and reaction time (Landeghem \& Persoons, 2001), which relates to security of supply and other identified decision criteria. 
Some challenges related to benchmarking supply chains in healthcare logistics have been addressed. Quantifying the importance of each decision criterion addresses the issue of differences in importance of performance measures and best practice across firms (Simatupang \& Sridharan, 2004), borders (van Lent et al., 2010), and context (Sousa \& Voss, 2001, 2008). According to Sousa and Voss, the contextual conditions of an organization determine the use and fit of operations management practices in an organization (Sousa \& Voss, 2001, 2008). This paper suggests that the suitability of a process design depends on the preference regarding certain decision criteria and that priorities may differ according to process type and organizational/national context. However, there seems to be agreement on the most important decision criteria.

\section{Conclusions and limitations}

This paper contributes to the limited performance measurement and benchmarking literature identified in the field of healthcare logistics. First, a method for benchmarking healthcare logistics processes is proposed. A set of 17 decision criteria has been identified that should be considered when designing logistics processes in a healthcare setting. Second, quality measures, security of supply and employee engagement were found to be the most important decision criteria across process types, organizational borders and country borders, and therefore most suitable as generalizable benchmarking metrics. Thus, the need for quality focused benchmarking in healthcare is addressed. Moreover, the study stresses the importance of human factors and HRM in the delivery of high quality logistics services in hospitals, which extant literature fails to recognize. Furthermore, addressing security of supply helps achieve supply chain reliability in a healthcare setting. Fourth, the proposed method copes with challenges related to healthcare supply chain benchmarking, particularly differences in importance of performance aspects and benchmarking across borders. Fifth, the country setting seems 
to determine the importance of decision criteria rather than process type.

The findings of this study are relevant for decision makers within healthcare logistics to understand 1) which decision criteria are important for designing logistics processes in a healthcare setting and 2) how this understanding can be used for benchmarking. However, more literature is needed on benchmarking and best practices in healthcare logistics. E.g. what should be benchmarked and what is the best process design under which circumstances? Moreover, the financial aspect found in benchmarking literature has deliberately been excluded from the current study. The authors recognize the importance of this aspect in the decision process and a financial analysis is seen as complementary to this study. Another limitation of this study is that there is no comparison to a Danish pharmaceutical distribution process. Furthermore, the study is limited to two types of processes. Future studies should be conducted in other countries and for other logistics processes in hospitals or even other industries. A survey on a larger population of hospitals would enable statistical analyses to further validate the findings of this study. In addition, specific process improvement philosophies or strategies such as lean or agility could be assessed using the identified decision criteria. Such research would fall within the research stream of operations management practice contingency research, e.g. (Sousa \& Voss, 2001, 2008).

\section{References}

Aitken, J., Childerhouse, P., Deakins, E., \& Towill, D. (2016). A comparative study of manufacturing and service sector supply chain integration via the uncertainty circle model. The International Journal of Logistics Management, 27(1), 188205. http://doi.org/ISSN 0957-4093

Al-Shaqha, W. M. S., \& Zairi, M. (2000). Re-engineering pharmaceutical care: towards a patient-focused care approach. International Journal of Health Care Quality Assurance, 13(5), 208-217. http://doi.org/10.1108/09526860010342707 
Alstete, J. W. (2008). Measurement benchmarks or "real" benchmarking?: An examination of current perspectives. Benchmarking: An International Journal, 15(2), 178-186. http://doi.org/10.1108/14635770810864884

Altuntaş Vural, C., \& Tuna, O. (2016). The prioritisation of service dimensions in logistics centres: a fuzzy quality function deployment methodology. International Journal of Logistics Research and Applications, 19(3), 159-180. http://doi.org/10.1080/13675567.2015.1008438

Aptel, O., Pomberg, M., \& Pourjalali, H. (2009). Improving Activities of Logistics Departments in Hospitals: A Comparison of French and U.S. Hospitals. Journal of Applied Management Accounting Research, 7(2), 1-20.

Aronsson, H., Abrahamsson, M., \& Spens, K. (2011). Developing lean and agile health care supply chains. Supply Chain Management: An International Journal, 16(3), 176-183. http://doi.org/10.1108/13598541111127164

Bachouch, R. Ben, Guinet, A., \& Hajri-Gabouj, S. (2012). An Integer linear model for hospital bed planning. International Journal of Production Economics, 140(2), 833-843. http://doi.org/10.1016/j.ijpe.2012.07.023

Bagchi, P. K. (1996). Role of benchmarking as a competitive strategy: the logistics experience. International Journal of Physical Distribution \& Logistics Management, 26(2), 4-22. http://doi.org/10.1108/09600039610113173

Bertolini, M., Bevilacqua, M., Ciarapica, F. E., \& Giacchetta, G. (2011). Business process re-engineering in healthcare management: a case study. Business Process Management Journal, 17(1), 42-66. http://doi.org/10.1108/14637151111105571

Blumberg, D. F. (1994). Strategic Benchmarking of Service Logistic Support Operations. Journal of Business Logistics, 15(2), 89-119.

Boudreau, J., Hopp, W., McClain, J. O., \& Thomas, L. J. (2003). On the Interface Between Operations and Human Resources Management. Manufacturing \& Service Operations Management, 5(3), 179-202. http://doi.org/10.1287/msom.5.3.179.16032

Bourcier, E., Madelaine, S., Archer, V., Kramp, F., Paul, M., \& Astier, A. (2016). Implementation of automated dispensing cabinets for management of medical devices in an intensive care unit: organisational and financial impact. European Journal of Hospital Pharmacy, 23(2), 86-90. http://doi.org/10.1136/ejhpharm2014-000604 
Böhme, T., Williams, S. J., Childerhouse, P., Deakins, E., \& Towill, D. (2013).

Methodology challenges associated with benchmarking healthcare supply chains. Production Planning \& Control, 24(10-11), 1002-1014. http://doi.org/10.1080/09537287.2012.666918

Böhme, T., Williams, S. J., Childerhouse, P., Deakins, E., \& Towill, D. (2016). Causes, effects and mitigation of unreliable healthcare supplies. Production Planning \& Control, 27(4), 249-262. http://doi.org/10.1080/09537287.2015.1105396

Callender, C., \& Grasman, S. E. (2010). Barriers and Best Practices for Material Management in the Healthcare Sector. Engineering Management Journal, 22(4), 11-19. http://doi.org/10.1080/10429247.2010.11431875

Camp, R. C. (1989a). Benchmarking: the search for industry best practices that lead to superior performance. Milwaukee, WI: Quality Press.

Camp, R. C. (1989b). Learning from the best leads to superior performance. Journal of Business Strategy, 13(3), 3-6. http://doi.org/10.1108/eb039486

Camp, R. C. (1995). Business process benchmarking: finding and implementing best practices. ASQC Quality Press.

Chang, H.-H. (1998). Determinants of Hospital Efficiency: the Case of Central Government-owned Hospitals in Taiwan. International Journal of Management Science, 26(2), 307-317. http://doi.org/10.1016/S0305-0483(98)00014-0

Chen, H.-K., Chen, H.-Y., Wu, H.-H., \& Lin, W.-T. (2004). TQM Implementation in a Healthcare and Pharmaceutical Logistics Organization: The Case of Zuellig Pharma in Taiwan. Total Quality Management \& Business Excellence, 15(910), 1171-1178. http://doi.org/10.1080/1478336042000255550

Chiarini, A. (2013). Waste savings in patient transportation inside large hospitals using lean thinking tools and logistic solutions. Leadership in Health Services, 26(4), 356-367. http://doi.org/10.1108/LHS-05-2012-0013

Chircu, A., Sultanow, E., \& Saraswat, S. P. (2014). Healthcare RFID In Germany: An Integrated Pharmaceutical Supply Chain Perspective. Journal of Applied Business Research, 30(3), 737-752. Retrieved from http://search.proquest.com/docview/1555715011?accountid=10297\%5Cnhttp://s fx.cranfield.ac.uk/cranfield?url_ver=Z39.882004\&rft_val_fmt=info:ofi/fmt:kev:mtx:journal\&genre=article\&sid=ProQ:ProQ :abiglobal\&atitle=Healthcare+RFID+In+Germany:+An+Integrated+Phar 
Council of Supply Chain Management Professionals. (2015). Definition of logistics management. Retrieved May 3, 2015, from https://cscmp.org/about-us/supplychain-management-definitions

Crosby, P. B. (1979). Quality is Free: The art of making quality certain. New York: New American Library.

Dattakumar, R., \& Jagadeesh, R. (2003). A review of literature on benchmarking. Benchmarking: An International Journal, 10(3), 176-209. http://doi.org/10.1108/14635770310477744

Daugherty, P. J., Dröge, C., \& Germain, R. (1994). Benchmarking Logistics in Manufacturing Firms. The International Journal of Logistics Management, 32(6), 409-430.

de Vries, J., \& Huijsman, R. (2011). Supply chain management in health services: an overview. Supply Chain Management: An International Journal, 16(3), 159165. http://doi.org/10.1108/13598541111127146

Díaz, A., Claes, B., Solís, L., \& Lorenzo, O. (2011). Benchmarking Logistics and Supply Chain Practices in Spain. Supply Chain Forum: An International Journal, 12(2), 82-90.

Dobrzykowski, D., Deilami, V. S., Hong, P., \& Kim, S.-C. (2014). A structured analysis of operations and supply chain management research in healthcare (1982-2011). International Journal of Production Economics, 147, 514-530. http://doi.org/10.1016/j.ijpe.2013.04.055

Dobson, G., Tilson, D., \& Tilson, V. (2015). Optimizing the timing and number of batches for compounded sterile products in an in-hospital pharmacy. Decision Support Systems, 76, 53-62. http://doi.org/10.1016/j.dss.2015.02.013

Elkhuizen, S. G., Limburg, M., Bakker, P. J. M., \& Klazinga, N. S. (2006). Evidencebased re-engineering: re-engineering the evidence: A systematic review of the literature on business process redesign (BPR) in hospital care. International Journal of Health Care Quality Assurance, 19(6), 477-499. http://doi.org/10.1108/09526860610686980

Elleuch, H., Hachicha, W., \& Chabchoub, H. (2014). A combined approach for supply chain risk management: description and application to a real hospital pharmaceutical case study. Journal of Risk Research, 17(5), 641-663. http://doi.org/10.1080/13669877.2013.815653 
Falan, S., \& Han, B. (2011). Moving towards efficient, safe, and meaningful healthcare: issues for automation. International Journal of Electronic Healthcare, 6(1), 7693. Retrieved from http://www.ncbi.nlm.nih.gov/pubmed/21406353

Gebicki, M., Mooney, E., Chen, S.-J. (Gary), \& Mazur, L. M. (2014). Evaluation of hospital medication inventory policies. Health Care Management Science, 17(3), 215-229. http://doi.org/10.1007/s10729-013-9251-1

Geiger, N. F. (2012). On Tying Medicare Reinbursement to Patient Satisfaction Surveys. American Journal of Nursing, 112(7), 11.

Grosse, E. H., Glock, C. H., Jaber, M. Y., \& Neumann, W. P. (2015). Incorporating human factors in order picking planning models: framework and research opportunities. International Journal of Production Research, 53(3), 695-717. http://doi.org/10.1287/inte.1040.0083

Ham, C., Kipping, R., \& McLeod, H. (2003). Redesigning work processes in health care: Lessons from the National Health Service. Milbank Quarterly, 81(3), 415439. http://doi.org/10.1111/1468-0009.t01-3-00062

Hanman, S. (1997). Benchmarking your firm's performance with best practice. The International Journal of Logistics Management, 8(2), 1-18. Retrieved from http://www.ingentaconnect.com/content/mcb/ijlm/1997/00000008/00000002/art 00001

Hassan, D. (2005). Measuring performance in the healthcare field: A multiple stakeholders’ perspective. Total Quality Management \& Business Excellence, 16(8-9), 945-953. http://doi.org/10.1080/14783360500163086

Hastreiter, S., Buck, M., Jehle, F., \& Wrobel, H. (2013). Benchmarking logistics services in German hospitals: a research status quo. In 10th International Conference on Service Systems and Service Management (pp. 1-6). Hong Kong: IEEE.

Heinbuch, S. E. (1995). A case of successful technology transfer to health care: Total quality materials management and just-in-time. Journal of Management in Medicine, 9(2), 48-56. http://doi.org/10.1108/02689239510086524

Holm, L. B., Lurås, H., \& Dahl, F. a. (2013). Improving hospital bed utilisation through simulation and optimisation: with application to a $40 \%$ increase in patient volume in a Norwegian General Hospital. International Journal of Medical Informatics, 82(2), 80-9. http://doi.org/10.1016/j.ijmedinf.2012.05.006 
Hong, P., Hong, S. W., Roh, J. J., \& Park, K. (2012). Evolving benchmarking practices: a review for research perspectives. Benchmarking: An International Journal, 19(4), 444-462. http://doi.org/10.1108/14635771211257945

Hung, R. Y.-Y. (2006). Business process management as competitive advantage: a review and empirical study. Total Quality Management \& Business Excellence, 17(1), 21-40. http://doi.org/10.1080/14783360500249836

Huselid, M. (1995). The Impact of Human Resource Management Practices on Turnover, Productivity, and Corporate Financial Performance. Academy of Management Journal, 38(3), 635-672. http://doi.org/10.2307/256741

Hussey, P. S., de Vries, H., Romley, J., Wang, M. C., Chen, S. S., Shekelle, P. G., \& McGlynn, E. a. (2009). A systematic review of health care efficiency measures. Health Services Research, 44(3), 784-805. http://doi.org/10.1111/j.14756773.2008.00942.x

Jehle, F., Woratschek, H., Schröder, J., Horbel, C., Tomanek, D. P., Stadtelmann, M., \& Weismann, F. (2015). Benchmarking-Studie Patiententransportlogistik (PTL). In Wertschöpfungsorientiertes Benchmarking (pp. 155-181). Berlin-Heidelberg: Springer-Verlag Berlin Heidelberg. http://doi.org/10.1007/978-3-662-43718-6

Joosten, T., Bongers, I., \& Janssen, R. (2009). Application of lean thinking to health care: issues and observations. International Journal for Quality in Health Care, 21(5), 341-347.

Jurado, I., Maestre, J. M., Velarde, P., Ocampo-Martinez, C., Fernández, I., Tejera, B. I., \& del Prado, J. R. (2016). Stock management in hospital pharmacy using chance-constrained model predictive control. Computers in Biology and Medicine, 72, 248-255. http://doi.org/10.1016/j.compbiomed.2015.11.011

Kanji, G., \& Moura e Sá, P. (2003). Sustaining healthcare excellence through performance measurement. Total Quality Management \& Business Excellence, 14(3), 269-289. http://doi.org/10.1080/1478336032000046607

Kilibarda, M., Zečević, S., \& Vidović, M. (2012). Measuring the quality of logistics service as an element of the logistics provider offering. Total Quality Management \& Business Excellence, 23(12), 1345-1361.

Klazinga, N., Fischer, C., \& ten Asbroek, A. (2011). Health services research related to performance indicators and benchmarking in Europe. Journal of Health Services Research \& Policy, 16(2), 38-47. http://doi.org/10.1258/jhsrp.2011.011042 
Korpela, J., \& Tuominen, M. (1996). Benchmarking logistics performance with an application of the analytic hierarchy process. IEEE Transactions on Engineering Management, 43(3), 323-333. http://doi.org/10.1109/17.511842

Kouzmin, A., Löffler, E., Klages, H., \& Korac-Kakabadse, N. (1999). Benchmarking and performance measurement in public sectors: Towards learning for agency effectiveness. International Journal of Public Sector Management, 12(2), 121144. http://doi.org/10.1108/09513559910263462

Kriegel, J., Jehle, F., Dieck, M., \& Mallory, P. (2013). Advanced services in hospital logistics in the German health service sector. Logistics Research, 6(2-3), 47-56. http://doi.org/10.1007/s12159-013-0100-x

Kriegel, J., Jehle, F., Dieck, M., \& Tuttle-weidinger, L. (2015). Optimizing patient flow in Austrian hospitals - Improvement of patient- centered care by coordinating hospital-wide patient trails. International Journal of Healthcare Management, 8(2), 89-99.

Kriegel, J., Jehle, F., Moser, H., \& Tuttle-Weidinger, L. (2016). Patient logistics management of patient flows in hospitals: A comparison of Bavarian and Austrian hospitals. International Journal of Healthcare Management, 1-12. http://doi.org/10.1080/20479700.2015.1119370

Kumar, A., \& Rahman, S. (2014). RFID-Enabled Process Reengineering of Closed-loop Supply Chains in the Healthcare Industry of Singapore. Journal of Cleaner Production, 85, 382-394. http://doi.org/10.1016/j.jclepro.2014.04.037

Lambert, T. E., Min, H., \& Srinivasan, A. K. (2009). Benchmarking and measuring the comparative efficiency of emergency medical services in major US cities. Benchmarking: An International Journal, 16(4), 543-561. http://doi.org/10.1108/14635770910972450

Landeghem, R. Van, \& Persoons, K. (2001). Benchmarking of logistical operations based on a causal model. International Journal of Operations \& Production Management, 21(1), 254-267. http://doi.org/10.1108/01443570110358576

Lee, G. M., Kleinman, K., Soumerai, S. B., Tse, A., Cole, D., Fridkin, S. K., ... Jha, A. K. (2012). Effect of Nonpayment for Preventable Infections in U.S. Hospitals. New England Journal of Medicine, 367(15), 1428-1437. http://doi.org/10.1056/NEJMsa1202419

Lee, S. M., Lee, D., \& Schniederjans, M. J. (2011). Supply chain innovation and organizational performance in the healthcare industry. International Journal of 
Operations \& Production Management, 31(11), 1193-1214.

http://doi.org/10.1108/01443571111178493

Lega, F., Marsilio, M., \& Villa, S. (2012). An evaluation framework for measuring supply chain performance in the public healthcare sector: evidence from the Italian NHS. Production Planning \& Control, 24(10-11), 931-947. http://doi.org/10.1080/09537287.2012.666906

Lega, F., Prenestini, A., \& Spurgeon, P. (2013). Is management essential to improving the performance and sustainability of health care systems and organizations? A systematic review and a roadmap for future studies. Value in Health, 16(1), 4651. http://doi.org/10.1016/j.jval.2012.10.004

Lewis, M., \& Hartley, J. (2001). Evolving forms of quality management in local government: lessons from the Best Value pilot programme. Policy and Politics, 29(4), 477-496. Retrieved from isi:000172544300007

Lifvergren, S., Gremyr, I., Hellström, A., Chakhunashvili, A., \& Bergman, B. (2010). Lessons from Sweden's first large-scale implementation of Six Sigma in healthcare. Operations Management Research, 3(3-4), 117-128. http://doi.org/10.1007/s12063-010-0038-y

Locke, E. A., \& Latham, G. P. (2002). Building a practically useful theory of goal setting and task motivation: A 35-year odyssey. American Psychologist, 57(9), 705-717.

Longo, M., \& Masella, C. (2002). Organisation of operating theatres: an Italian benchmarking study. International Journal of Operations \& Production Management, 22(4), 425-444. http://doi.org/10.1108/01443570210420421

Magd, H., \& Curry, A. (2003). Benchmarking: achieving best value in public-sector organisations. Benchmarking: An International Journal, 10(3), 261-286. http://doi.org/10.1108/14635770310477780

Mayle, D. T., Hinton, C. M., Francis, G. A. J., \& Holloway, J. A. (2002). What really goes on in the name of benchmarking? In A. Neely (Ed.), Business performance management (pp. 211-224). Cambridge, MA: Cambridge University Press.

McCutcheon, D. M., \& Meredith, J. R. (1993). Conducting case study research in operations management. Journal of Operations Management, 11(3), 239-256. http://doi.org/10.1016/0272-6963(93)90002-7 
Mckone-Sweet, K. E., Hamilton, P., \& Willis, S. B. (2005). The Ailing Healthcare Supply Chain: A Prescription for Change. Journal of Supply Chain Management, 41(1), 4-17.

Mentzer, J. T., \& Konrad, B. P. (1991). An efficiency/effectiveness approach to logistics performance analysis. Journal of Business Logistics, 12(1), 33-61.

Min, H. (2004). An examination of warehouse employee recruitment and retention practices in the USA. International Journal of Logistics: Research and Applications, 7(4), 345-359. http://doi.org/10.1080/13675560412331282948

Min, H. (2007). Examining sources of warehouse employee turnover. International Journal of Physical Distribution \& Logistics Management, 37(5), 375-388. http://doi.org/10.1108/09600030710758437

Mosel, D., \& Gift, B. (1994). Collaborative benchmarking in health care. The Joint Commission Journal on Quality Improvement, 20(5), 239-249.

Narayana, S. A., Elias, A. A., \& Pati, R. K. (2014). Reverse logistics in the pharmaceuticals industry: a systemic analysis. The International Journal of Logistics Management, 25(2), 379-398. http://doi.org/10.1108/IJLM-08-20120073

Nayar, P., Ozcan, Y. A., Yu, F., \& Nguyen, A. T. (2013). Benchmarking urban acute care hospitals: efficiency and quality perspectives. Health Care Management Review, 38(2), 137-45. http://doi.org/10.1097/HMR.0b013e3182527a4c

Neely, A., Gregory, M., \& Platts, K. (2005). Performance measurement system design: A literature review and research agenda. International Journal of Operations \& Production Management, 25(12), 1228-1263. http://doi.org/10.1108/01443570510633639

Neely, A., Adams, C., \& Kennerley, M. (2002). The Performance Prism: The Scorecard for Measuring and Managing Business Success. London: Prentice Hall Financial Times.

Northcott, D., \& Llewellyn, S. (2003). The "ladder of success” in healthcare: The UK national reference costing index. Management Accounting Research, 14(1), 5166. http://doi.org/10.1016/S1044-5005(02)00032-X

Northcott, D., \& Llewellyn, S. (2005). Benchmarking in UK health: a gap between policy and practice? Benchmarking: An International Journal, 12(5), 419-435. http://doi.org/10.1108/14635770510619357 
OECD. (2015). Health at a Glance 2015 - OECD Indicators. Retrieved from http://www.keepeek.com/Digital-Asset-Management/oecd/social-issuesmigration-health/health-at-a-glance-2015/pharmaceuticalconsumption_health_glance-2015-68-en\#page2

Ozcan, Y. A. (2008). Health Care Benchmarking and Performance Evaluation - An Assessment using Data Envelopment Analysis (DEA). New York: Springer Science + Business Media, LLC.

Pan, Z. X. (Thomas), \& Pokharel, S. (2007). Logistics in hospitals: a case study of some Singapore hospitals. Leadership in Health Services, 20(3), 195-207. http://doi.org/10.1108/17511870710764041

Papalexi, M., Bamford, D., \& Dehe, B. (2016). A case study of kanban implementation within the pharmaceutical supply chain. International Journal of Logistics Research and Applications, 19(4), 239-255. http://doi.org/10.1080/13675567.2015.1075478

Pinna, R., Carrus, P. P., \& Marras, F. (2015). The drug logistics process: an innovative experience. The TQM Journal, 27(2), 214-230. http://doi.org/10.1108/TQM-012015-0004

Poulin, É. (2003). Benchmarking the hospital logistics process. CMA Management, 77(1), 20-23.

Poulymenopoulou, M., Malamateniou, F., \& Vassilacopoulos, G. (2012). Emergency Healthcare Process Automation Using Mobile Computing and Cloud Services. Journal of Medical Systems, 36(5), 3233-3241. http://doi.org/10.1007/s10916011-9814-y

Privett, N., \& Gonsalvez, D. (2014). The top ten global health supply chain issues : Perspectives from the field. Operations Research for Health Care, 3(4), 226230. http://doi.org/10.1016/j.orhc.2014.09.002

Ralston, P. M., Grawe, S. J., \& Daugherty, P. J. (2013). Logistics salience impact on logistics capabilities and performance. The International Journal of Logistics Management, 24(2), 136-152. http://doi.org/10.1108/IJLM-10-2012-0113

Rodwell, J. R., Lam, J., \& Fastenau, M. (2000). Benchmarking HRM and the benchmarking of benchmarking. Employee Relations, 22(4), 356-374.

Romero, A., \& Lefebvre, E. (2015). Combining barcodes and RFID in a hybrid solution to improve hospital pharmacy logistics processes. International Journal of Information Technology and Management, 14(2/3), 97-123. 
Rosales, C. R., Magazine, M., \& Rao, U. (2014). Point-of-Use Hybrid Inventory Policy for Hospitals. Decision Sciences, 45(5), 913-937. http://doi.org/10.1111/deci.12097

Rosenthal, M. B. (2007). Nonpayment for performance? Medicare’s new reimbursement rule. New England Journal of Medicine, 357(16), 1573-1575. http://doi.org/10.1056/NEJMp1002530

Saltman, R. B., \& Figueras, J. (1997). European health care reform - Analysis of current strategies. Copenhagen.

Sargiacomo, M. (2002). Benchmarking in Italy: The first case study on personnel motivation and satisfaction in a Health Business. Total Quality Management, 13(4), 489-505. http://doi.org/10.1080/09544120220149296

Schmidt, R., Geisler, S., \& Spreckelsen, C. (2013). Decision support for hospital bed management using adaptable individual length of stay estimations and shared resources. BMC Medical Informatics and Decision Making, 13(3), 1-19. http://doi.org/10.1186/1472-6947-13-3

Shah, N. (2004). Pharmaceutical supply chains: Key issues and strategies for optimisation. Computers and Chemical Engineering, 28(6), 929-941. http://doi.org/10.1016/j.compchemeng.2003.09.022

Simatupang, T. M., \& Sridharan, R. (2004). Benchmarking supply chain collaboration an empirical study. Benchmarking: An International Journal, 11(5), 484-503. http://doi.org/10.1108/14635770410557717

Simpson, M., Kondouli, D., \& Wai, P. H. (1999). From benchmarking to business process re-engineering : a case study. Total Quality Management, 10(4/5), 717724.

Smith, A. D., \& Offodile, O. F. (2008). Data collection automation and total quality management: case studies in the health-service industry. Health Marketing Quarterly, 25(3), 217-240. http://doi.org/10.1080/07359680802081811

Sousa, R., \& Voss, C. A. (2001). Quality Management: Universal or Context Dependent? Production and Operations Management, 10(4), 383-404.

Sousa, R., \& Voss, C. A. (2008). Contingency research in operations management practices. Journal of Operations Management, 26(6), 697-713. http://doi.org/10.1016/j.jom.2008.06.001

Souza, L. B. De. (2009). Trends and approaches in lean healthcare. Leadership in Health Services, 22(2), 121-139. http://doi.org/10.1108/17511870910953788 
Swinehart, K. D., \& Smith, A. E. (2005). Internal supply chain performance measurement: A health care continuous improvement implementation. International Journal of Health Care Quality Assurance, 18(7), 533-542. http://doi.org/10.1108/09526860510627210

Taner, M. T., Sezen, B., \& Antony, J. (2007). An overview of six sigma applications in healthcare industry. International Journal of Health Care Quality Assurance, 20(4), 329-340. http://doi.org/10.1108/09526860710754398

Thai, V. V. (2013). Logistics service quality: conceptual model and empirical evidence. International Journal of Logistics Research and Applications, 16(2), 114-131. http://doi.org/10.1080/13675567.2013.804907

Tilson, V., Dobson, G., Haas, C. E., \& Tilson, D. (2014). Mathematical Modeling to Reduce Waste of Compounded Sterile Products in Hospital Pharmacies. Hospital Pharmacy, 49(7), 616-627. http://doi.org/10.1310/hpj4907-616

Troolin, P. (2000). Benchmarking the supply side. Materials Management in Health Care, 9(1), 36-38.

Utley, M., Gallivan, S., Davis, K., Daniel, P., Reeves, P., \& Worrall, J. (2003). Estimating bed requirements for an intermediate care facility. European Journal of Operational Research, 150(1), 92-100. http://doi.org/10.1016/S03772217(02)00788-9

Van der Wees, P. J., Nijhuis-van der Sanden, M. W. G., van Ginneken, E., Ayanian, J. Z., Schneider, E. C., \& Westert, G. P. (2014). Governing healthcare through performance measurement in Massachusetts and the Netherlands. Health Policy, 116(1), 18-26. http://doi.org/10.1016/j.healthpol.2013.09.009

van Lent, W. A. M., de Beer, R. D., \& van Harten, W. H. (2010). International benchmarking of specialty hospitals. A series of case studies on comprehensive cancer centres. BMC Health Services Research, 10, 253-263. http://doi.org/10.1186/1472-6963-10-253

van Lent, W. A. M., Sanders, E. M., \& van Harten, W. H. (2012). Exploring improvements in patient logistics in Dutch hospitals with a survey. BMC Health Services Research, 12(1), 232. http://doi.org/10.1186/1472-6963-12-232

VandeWalle, D., Cron, W. L., \& Slocum Jr., J. W. (2001). The Role of Goal Orientation Following Performance Feedback. Journal of Applied Psychology, 86(4), 629640. 
Villa, S., Barbieri, M., \& Lega, F. (2009). Restructuring patient flow logistics around patient care needs: implications and practicalities from three critical cases. Health Care Management Science, 12(2), 155-165. http://doi.org/10.1007/s10729-008-9091-6

Villa, S., Prenestini, A., \& Giusepi, I. (2014). A framework to analyze hospital-wide patient flow logistics: Evidence from an Italian comparative study. Health Policy, 115(2-3), 196-205. http://doi.org/10.1016/j.healthpol.2013.12.010

Volland, J., Fügener, A., Schoenfelder, J., \& Brunner, J. O. (2016). Material Logistics in Hospitals : A Literature Review. Omega, In press. http://doi.org/10.1016/j.omega.2016.08.004

Voss, C., Tsikriktsis, N., \& Frohlich, M. (2002). Case research in operations management. International Journal of Operations \& Production Management, 22(2), 195-219. http://doi.org/10.1108/01443570210414329

Voss, C. A., Åhlström, P., \& Blackmon, K. (1997). Benchmarking and operational performance: some empirical results. International Journal of Operations \& Production Management, 17(10), 1046-1058.

Wamba, S. F., \& Ngai, E. W. T. (2015). Importance of issues related to RFID-enabled healthcare transformation projects: results from a Delphi study. Production Planning \& Control, 26(1), 19-33. http://doi.org/10.1080/09537287.2013.840015

Wamba, S. F., Anand, A., \& Carter, L. (2013). A literature review of RFID-enabled healthcare applications and issues. International Journal of Information Management, 33(5), 875-891. http://doi.org/10.1016/j.ijinfomgt.2013.07.005

Whitson, D. (1997). Applying just-in-time systems in health care. IIE Solutions, 29(8), 32-37. Retrieved from http://search.proquest.com/docview/231454670?accountid=14744

WHO. (2010). The World Health Report - Health Systems Financing.

Wieser, P. (2011). From Health Logistics to Health Supply Chain Management. Supply Chain Forum: An International Journal, 12(1), 4-14.

Wong, W. P., \& Wong, K. Y. (2008). A review on benchmarking of supply chain performance measures. Benchmarking: An International Journal, 15(1), 25-51. http://doi.org/10.1108/14635770810854335 
Wynn-Williams, K. L. H. (2005). Performance assessment and benchmarking in the public sector: An example from New Zealand. Benchmarking: An International Journal, 12(5), 482-492. http://doi.org/10.1108/14635770510619393

Xie, Y., \& Breen, L. (2014). Who cares wins? A comparative analysis of household waste medicines and batteries reverse logistics systems - The case of the NHS (UK). Supply Chain Management: An International Journal, 19(4), 455-474. http://doi.org/10.1108/SCM-07-2013-0255

Xiong, J., He, Z., Ke, B., \& Zhang, M. (2015). Development and validation of a measurement instrument for assessing quality management practices in hospitals: an exploratory study. Total Quality Management \& Business Excellence, 27(5-6), 465-478. http://doi.org/10.1080/14783363.2015.1012059

Yasin, M. M., Zimmerer, L. W., Miller, P., \& Zimmerer, T. W. (2002). An empirical investigation of the effectiveness of contemporary managerial philosophies in a hospital operational setting. International Journal of Health Care Quality Assurance, 15(6), 268-276. http://doi.org/10.1108/09526860210442038

Yazici, H. J. (2014). An exploratory analysis of hospital perspectives on real time information requirements and perceived benefits of RFID technology for future adoption. International Journal of Information Management, 34(5), 603-621. http://doi.org/10.1016/j.ijinfomgt.2014.04.010

Yin, R. K. (1994). Case study research - design and methods. Sage.

Zhu, Z., Hen, B. H., \& Teow, K. L. (2012). Estimating ICU bed capacity using discrete event simulation. International Journal of Health Care Quality Assurance, 25(2), 134-144. http://doi.org/10.1108/09526861211198290 


\section{Appendix A}

Appendix A provides the interview guide used for the first round of interviews carried out for each investigated process.

\section{Preparation}

Background: The project focuses on how to improve logistical processes in hospitals, particularly through the use of technologies and changes to the process steps. The bed logistics process and pharmaceutical distribution process are in focus.

Purpose: To learn about the process, the challenges in the process, the reasons for implementing improvement initiatives (process changes, implementation of technologies etc.), and the effects of these changes (on logistics, technology, structure, and procedure).

\section{Interview questions}

\section{Background questions}

1) What is your role?

2) What are the responsibilities of your department?

a. Which tasks do you undertake?

b. Do you have different units in your department?

c. Do you have an organizational chart available for me to see?

d. How many people work there?

3) Describe the process steps of the process

\section{The use of technologies and the implementation of process changes}

4) Which technologies / process changes have you implemented?

5) When did you start using these technologies / process changes?

6) What do you use the technologies for?

7) Why did you decide to use these technologies / process changes?

a. What were the main drivers for deciding to use that technology rather than other technologies?

b. Do the reasons vary depending on the process?

c. Which challenges did you hope to overcome by implementing technologies?

d. Which decision parameters did you use? 
8) Validate decision indicators in framework - were others used? Where some not used?

9) Did you test other types of technologies in those processes before implementing?

10) What were the main challenges in the process before you implemented the technologies / made process changes?

11) What are the main challenges for the processes now?

12) What challenges have you had with the technologies?

13) Have any of the technologies that you have implemented / tried to implement failed?

a. If so, why?

14) What have been the main benefits of implementing technologies?

15) What good or bad effects have you experienced after implementing the technologies or other improvement initiatives?

16) How do employees interact with the technologies?

17) When would you choose to use technologies over other types of improvement?

18) When would you rather use human resources?

19) How have the employees received the use of technologies?

\section{Data and performance measurement}

20) Do you use any KPIs to measure process performance?

a. If yes, which KPIs do you use?

b. Why have you chosen those KPIs?

c. How do you capture data to measure the KPIs? (RFID, barcodes?)

d. Have your KPIs improved since implementing technologies / change initiatives?

i. Are the improvements also due to other improvement initiatives?

ii. How much did the KPIs improve?

21) Do you consider the process a good process?

a. Why / why not?

22) Is the process best practice?

a. Why / why not?

b. What characterizes the process?

\section{Future prospects}

23) Do you see the implemented technologies as something you would invest in in the future or are there other technologies that are more interesting?

24) If you could have three wishes granted for the processes, what would that be?

25) Any changes in pipeline?

\section{Documents and further research}

26) Do you have any process maps that I can have a look at? 
27) Do you have any presentations/proposals for implementing AGVs that I may see?

28) Do you have any executive reports on performance that I may see?

29) Can I use my findings for publication?

30) Further interviews and observations possible?

a. Process observations possible?

b. Employee shadowing possible?

c. Follow-up interviews possible?

31) Thank you for your time - anything to add? 


\section{Appendix B}

Table A depicts the survey sent out to decision makers in the bed logistics and pharmaceutical logistics case studies. The respondents were asked to weight the decision criteria on a 0-10 scale according to their importance when improve healthcare logistics processes.

Table B. Validation of identified decision criteria

\begin{tabular}{|c|c|c|}
\hline Decision criterion & Description & Weight (0-10) \\
\hline Lead time & Time from order to delivery. & \\
\hline Value-added time & \% of lead time adding value. & \\
\hline Security of supply & $\begin{array}{l}\text { Ensuring the right amount at the right } \\
\text { time. }\end{array}$ & \\
\hline Traceability & Enabling track and trace. & \\
\hline Degree of automation & How automated is the process? & \\
\hline Information management & $\begin{array}{l}\text { The ability to collect, analyze and } \\
\text { communicate data. }\end{array}$ & \\
\hline Environmental considerations & $\begin{array}{l}\text { Sustainable use of energy, chemicals, } \\
\text { renewable materials etc. }\end{array}$ & \\
\hline Risk of mistakes & Likelihood of mistakes occurring. & \\
\hline Consistency & $\begin{array}{l}\text { Standardization of the process and process } \\
\text { output. }\end{array}$ & \\
\hline Future proofing & $\begin{array}{l}\text { Will the solution sustain in five years? Is } \\
\text { it flexible? }\end{array}$ & \\
\hline Impact on related processes & $\begin{array}{l}\text { Negative and positive impact on other } \\
\text { processes. E.g. other use for technology or } \\
\text { increased workload for others. }\end{array}$ & \\
\hline Output quality & Quality of product/service delivered. & \\
\hline Competence shift (handovers) & Number of handovers in the process. & \\
\hline Competence match & $\begin{array}{l}\text { Do the competencies of the employees } \\
\text { match the needs of the new process or is } \\
\text { training needed? }\end{array}$ & \\
\hline Unnecessary process & Can the process be avoided? & \\
\hline Employee engagement & $\begin{array}{l}\text { Is the employee motivated to perform the } \\
\text { job? Is an incentive provided? }\end{array}$ & \\
\hline Employee work conditions & $\begin{array}{l}\text { Employee safety, work load, strenuous } \\
\text { work, ergonomics, physical and } \\
\text { psychological work environment. }\end{array}$ & \\
\hline
\end{tabular}

